\title{
Vitamin D and Ageing: Neurological Issues
}

\author{
Cédric Annweiler ${ }^{a, b, d}$ Anne-Marie Schott ${ }^{e, f}$ Gilles Berrut ${ }^{g, h}$ \\ Valérie Chauviré ${ }^{a, c}$ Didier Le Gall ${ }^{a} d \quad$ Marco Inzitari ${ }^{i}$ Olivier Beauchet ${ }^{a, b, d}$ \\ ${ }^{a}$ Angers University Memory Center, and Departments of ${ }^{b}$ Internal Medicine and Geriatrics and c Neurology,

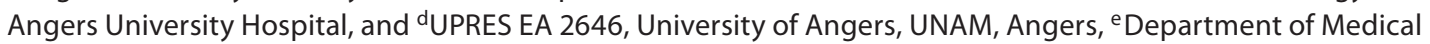 \\ Information, Lyon University Hospital and f University of Lyon, Lyon, and ${ }^{9}$ Department of Geriatrics, \\ Nantes University Hospital, and ' University of Nantes, UNAM, Nantes, France; i Socio-Sanitary Hospital Pere Virgili \\ and Institute on Aging of the Autonomous University of Barcelona, Barcelona, Spain
}

\section{Key Words}

Vitamin D • Central nervous system • Life span •

Neuro-psychogeriatrics

\begin{abstract}
Objective: Vitamin D has been shown to have multiple biological targets mediated by the vitamin $D$ receptor present in many cells. Specific actions on the central nervous system (CNS) have been described. The objective of this review was to describe the relationship between vitamin $D$ and the nervous system throughout the different stages of life. Methods: A bibliographical search was performed in the MedLine and Cochrane library databases. The keywords used were: 'vitamin D' and 'nervous system' and/or 'central nervous system' and/or 'nervous system diseases' and/or 'psychological tests' and/or 'neuropsychological tests' and/or 'mental disorders'. The search period ranged from 01/01/1988 to $31 / 10 / 2009$. Two hundred and ninety-five abstracts were first identified after screening. A final selection of 127 articles was used for the purpose of this review. Results: The studies published over the past 20 years provide an increasing number of arguments in favor of a life-long role of vitamin D on the
\end{abstract}

nervous system as a whole, and in particular on the CNS. During cerebral development, vitamin D may act like a neurosteroid hormone in the areas of neurotransmission, neuroprotection, and neuroimmunomodulation. Moreover, vitamin $D$ deficiency has been associated with neurological and psychiatric disorders. In older adults, hypovitaminosis D has been associated with neuromuscular disorders, dementia, and Parkinson's disease. Thus, vitamin D supplementation might have a protective effect against these neurological disorders. Conclusions: Vitamin D has been associated with many neurological functions and its deficiency with dysfunction. Low serum 25-hydroxyvitamin D concentrations can potentially be reversed. This simple and low-cost correction might contribute to the primo-secondary prevention of various neuropsychiatric disorders.

Copyright $\odot 2010$ S. Karger AG, Basel

\section{Introduction}

Vitamin D is a secosteroid hormone typically associated with regulation of phosphocalcic homeostasis and osteogenesis [1]. The past decade was characterized by an

\section{KARGER \\ Fax +4161306 1234 \\ E-Mail karger@karger.ch}

www.karger.com
(C) 2010 S. Karger AG, Basel

0302-282X/10/0623-0139\$26.00/0

Accessible online at:

www.karger.com/nps
Cédric Annweiler, MD, MS

Department of Internal Medicine and Geriatrics

Angers University Hospital

FR-49933 Angers Cedex 9 (France)

Tel. +33 2413554 86, Fax +33 2413548 94, E-Mail CeAnnweiler@chu-angers.fr 
increased number of publications which highlighted that vitamin $\mathrm{D}$ was not only associated with bone disease, but also with non-bone adverse health outcomes, including immunosuppression, cancer, infections, and cardiovascular diseases $[1,2]$. These associations are related to the fact that vitamin $\mathrm{D}$ has multiple biological targets mediated by the vitamin $\mathrm{D}$ receptor (VDR) present in numerous cells [1].

Vitamin-D-related effects upon the central nervous system (CNS) have been described less than other target organs [1], but it appears that vitamin D deficiency is associated with neurological dysfunction $[1,2]$. The objective of this literature review was to describe the relationship between vitamin D and the nervous system throughout the different stages of life.

\section{Methods}

The bibliographical search consisted of an English and French literature review of the MedLine and Cochrane library databases. The search period ranged from $01 / 01 / 1988$ to $31 / 10 / 2009$. The following Medical Subject Headings $(\mathrm{MeSH})$ terms were used: 'vitamin D' and 'nervous system' and/or 'central nervous system' and/ or 'nervous system diseases' and/or 'psychological tests' and/or 'neuropsychological tests' and/or 'mental disorders'. The search also included the reference lists of the retrieved articles. In order to ensure a comprehensive approach, additional key studies known to the authors that did not meet the search criteria were also included. Abstracts identified with the literature search were independently evaluated by 2 reviewers (C.A. and O.B.). Two hundred and ninety-five abstracts were first identified after screening.

Final selection criteria were applied when neurological, mental, or neuropsychological data were used as the outcome, and when a serum 25 -hydroxyvitamin $\mathrm{D}_{2}\left(25-\mathrm{OHD}_{2}\right)$ concentration was provided and/or vitamin $\mathrm{D}$ and analog supplementation was used. A final selection of 127 articles was used for the purpose of this review.

\section{Results}

\section{Mechanism of Action of Vitamin D}

Vitamin $\mathrm{D}$ can be ingested or synthesized in the skin under the action of ultraviolet $\mathrm{B}$ (UVB) rays, resulting in a pre-vitamin $\mathrm{D}$ going through 2 successive hydroxylations, first in the liver and then in the kidney. Vitamin $\mathrm{D}$ can therefore be found in different forms, depending on the degree of hydroxylation: the active form is $1,25-$ dihydroxyvitamin $\mathrm{D}_{3}\left(1,25-(\mathrm{OH})_{2} \mathrm{D}_{3}\right)$ formed by $\alpha$-hydroxylation of $25-\mathrm{OHD}_{2} \cdot 1,25-(\mathrm{OH})_{2} \mathrm{D}_{3}$ regulates the expression of target tissues by binding primarily to the VDR
[1]. Mapping of the VDR has been performed, which confirmed the existence of non-bone target tissues for vitamin D, particularly brain tissues in rodents and humans, with a similar distribution of the VDR between both species $[1,3,4]$.

\section{Vitamin D and Neuro-Ontogenesis}

The impact of vitamin $\mathrm{D}$ during the natural development of the CNS during the embryonic period has been studied primarily in rodents. VDR develop in the CNS of rats from the 12th day of embryonic development [5]. They appear predominantly in the neuroepithelium in the early stages of neurogenesis, then in the subventricular zone of the lateral ventricles [5], where neural stem cells are found. VDR heterodimerization seems to play a part in the neuro-ontogenetic process. Prenatal vitamin $D$ deficiency is the model of choice to study these implications. McGrath et al. [6] created a Developmental Vitamin D model in rats, and established that the brain of rats born from mothers with a vitamin $\mathrm{D}$ deficiency during pregnancy was morphologically modified, with greater length, enlarged lateral ventricles, and a thinner cortex compared to control newborns [7]. In these animals, the mitotic cellular proliferation was significantly increased, the apoptotic phenomena were slowed down [7], and a dysregulation of synaptic plasticity and neurotransmission was observed, caused by the altered expression of 36 brain proteins [7] and mitochondrial disorders [8].

These observations confirm the key role of vitamin D in the regulation of neuroprogenitors, the proliferation and differentiation of the nervous tissue, and the control of the CNS metabolic pathways during embryogenesis.

\section{Vitamin D and Brain: The Bases of a Physiological Relationship}

In adults, vitamin D 25-hydroxylase and 25-hydroxyvitamin $\mathrm{D}-1 \alpha$-hydroxylase, but also 24 -hydroxylase, which degrades $25-\mathrm{OHD}_{2}$ and $1,25-(\mathrm{OH})_{2} \mathrm{D}_{3}$, are present in the brain, highlighting that the CNS contains all the enzymatic material required to locally metabolize its own active form of vitamin D. Vitamin D acts like an auto- or paracrine hormone of the neurosteroid type [11, $12]$, binding locally to the VDR expressed in the neural and glial cells of the temporal, orbital and cingulate cortex, but also in the thalamus, the nucleus accumbens, the stria terminalis, the amygdaloid complex, the olfactory network, and the spinal cord $[3,10]$. Such metabolic pathways support the role of vitamin D in brain homeostasis. Experimental studies in rodents have confirmed this action. 
Table 1. Key studies showing an association between serum vitamin D concentration or vitamin D supplementation and mental or neurological diseases

\begin{tabular}{|c|c|c|c|c|c|}
\hline \multirow{2}{*}{$\begin{array}{l}\text { Field of } \\
\text { research }\end{array}$} & \multirow[t]{2}{*}{ Disease or disorder } & \multicolumn{3}{|l|}{ Study design } & \multirow[t]{2}{*}{ Evidence } \\
\hline & & observational studies & clinical trials & experimental & \\
\hline \multirow{3}{*}{$\begin{array}{l}\text { Mental } \\
\text { diseases }\end{array}$} & behavior disorders & & & {$[25-31]$} & low \\
\hline & schizophrenia & $\begin{array}{l}{[37,38]} \\
263 \text { subjects, } 38.9 \text { years } \\
(13-85 \text { years })\end{array}$ & $\begin{array}{l}\text { [39] } \\
9,114 \text { subjects, } 31 \text { years } \\
\text { (supplementation: min. 2,000 IU/day during the first year } \\
\text { of life) }\end{array}$ & {$[36]$} & moderate \\
\hline & depression & $\begin{array}{l}{[32,37,43-45]} \\
1,591 \text { subjects, } 71.6 \text { years } \\
\text { (13-95 years) }\end{array}$ & $\begin{array}{l}{[48]} \\
15 \text { subjects, } 15-61 \text { years } \\
\text { (supplementation: } 1 \text { dose of } 100,000 \mathrm{IU} \text { ) }\end{array}$ & {$[27,31]$} & moderate \\
\hline \multirow[t]{4}{*}{$\begin{array}{l}\text { Nervous } \\
\text { system } \\
\text { diseases }\end{array}$} & epilepsy & $\begin{array}{l}{[52]} \\
3 \text { subjects, } 0.2 \text { years }\end{array}$ & $\begin{array}{l}{[53,54]} \\
24 \text { subjects, } 14.5 \text { years (6-32 years) } \\
\text { (supplementation: } 4,000 \text { IU/day for } 28 \text { days, then } 16,000 \\
\text { IU/day for } 28 \text { days or } 8,000 \text { IU/day for } 28 \text { days) }\end{array}$ & {$[23,55,56]$} & moderate \\
\hline & multiple sclerosis & $\begin{array}{l}{[59,61,63]} \\
973 \text { subjects, } 28.0 \text { years } \\
\text { (6-76 years) }\end{array}$ & $\begin{array}{l}{[68,69]} \\
188,117 \text { subjects ( } 25-58 \text { years) } \\
\text { (supplementation: dietary intakes) }\end{array}$ & {$[57,58,64]$} & high \\
\hline & cerebral tumor & & $\begin{array}{l}\text { [73] } \\
11 \text { subjects, } 54.4 \text { years }(49-71 \text { years) } \\
\text { (supplementation: } 0.04 \mu \mathrm{g} / \mathrm{kg} / \text { day) }\end{array}$ & {$[70-72,74-76]$} & low \\
\hline & cerebral ischemia & & & {$[16]$} & low \\
\hline \multirow[t]{2}{*}{$\begin{array}{l}\text { Neuro- } \\
\text { degenerative } \\
\text { diseases }\end{array}$} & Alzheimer's disease & $\begin{array}{l}{[43,97-103,105]} \\
4,289 \text { subjects, } 77.7 \text { years } \\
\text { (60-94 years) }\end{array}$ & $\begin{array}{l}{[116]} \\
69 \text { subjects, } 84 \text { years ( } 70-89 \text { years) } \\
\text { (supplementation: dietary intakes) }\end{array}$ & $\begin{array}{l}{[109,110,114,} \\
115]\end{array}$ & high \\
\hline & Parkinson's disease & $\begin{array}{l}{[119-122]} \\
751 \text { subjects, } 65.2 \text { years } \\
\text { (37-92 years) }\end{array}$ & $\begin{array}{l}{[125]} \\
1 \text { subject, } 47 \text { years } \\
\text { (supplementation: } 4,000 \text { IU/day) }\end{array}$ & {$[123,124]$} & low \\
\hline
\end{tabular}

Numbers of subjects and mean age (range) are calculated from all studied populations.

Neurotrophic Function and Neurotransmission

Vitamin D has the trophic functions of neuronal differentiation and maturation via control of the neurotrophin levels and the number of mitoses. In vitro, vitamin D increases the synthesis of neurotrophic agents, such as nerve growth factor (NGF), glial cell line-derived neurotrophic factor (GDNF), neurotrophin 3 (NT-3), as well as the synthesis of low-affinity p $75_{\mathrm{NTR}}$ receptors; it also accelerates neuronal growth in a dose-dependent manner in rat hippocampal cell cultures [14]. In the opposite way, the synthesis of neurotrophine 4 (NT-4) is slowed down by vitamin D [15]. Moreover, vitamin D plays a part in the regulation of numerous neurotransmitters in rat brain, including acetylcholine, dopamine, serotonin, and $\gamma$-aminobutyric acid $[1,11-13]$.

Vitamin D and the Central Nervous System

\section{Neuroprotection}

Such neurotrophic qualities make vitamin D a neuroprotective agent. As an example, trophic induction plays a neuroprotective role in cerebral ischemia [16] (table 1), as well as an anti-neurodegenerative role for dopaminergic cells in animal models of Parkinson's disease [11], and it also prevents neurotrophic deficits in diabetic rats [17].

The neuroprotective effect also results from intraneuronal calcium homeostasis being maintained via the regulation of voltage-dependent calcium channels [11], and via the synthesis of calcium-related cytoplasmic proteins such as parvalbumin or calbindin protein [18]. Moreover, it seems that vitamin D plays a part in the cerebral processes of detoxification by interacting with reactive oxygen and nitrogen species in the rat brain and by regulating the activity of $\gamma$-glutamyl transpeptidase [11, 19], a key enzyme in the antioxidative metabolism of glutathione. 
Concentrations of around 0.1-100 nmol 1,25- $(\mathrm{OH})_{2} \mathrm{D}_{3}$ thus ensure the efficient protection of neurons against the direct effects of superoxide ions and hydrogen peroxide [20]. Additionally, Garcion et al. [11] demonstrated that vitamin D inhibited the synthesis of inducible nitric oxide synthase, an enzyme produced in CNS cells in response to stress and which in high doses results in neuronal cell death. Finally, the protective properties of vitamin D against mineralization in the human brain should be highlighted $[1,21]$. Calcium deposits have been described in the basal ganglia of subjects with normal calcemia and phosphoremia alongside hypovitaminosis D.

\section{Neuroimmunomodulation}

VDR-dependent immunosuppressive effects, including increased concentrations of inflammatory cytokines, macrophages, and polynuclears, as well as their sensitization to apoptotic signals, have been described in the CNS [1]. Vitamin D additionally inhibits the expression of major histocompatibility complex class II proteins and cofactor 4 , which play an important part in the autoimmune processes of the nervous system [11]. As an example, in a model of mice with experimental allergic encephalitis (EAE), $1,25-\mathrm{OH}_{2} \mathrm{D}_{3}$ inhibited autoimmune neurological processes. However, vitamin D deficiency increased autoimmune damage [19]. Similarly, this effect disappeared in transgenic mice without functional cerebral VDR (or VDR knockout; VDR-KO) [22]; thus, confirming the roles of vitamin D and VDR in neuroimmunomodulation pathways. As such, vitamin D or its analogous agents could be considered as a new anti-inflammatory therapeutic class [1].

These experimental observations underline the central role of vitamin D in controlling the homeostasis of the CNS, from the embryonic period until adulthood. It therefore seems essential to maintain functioning VDR and high serum $25-\mathrm{OHD}_{2}$ concentrations throughout life to avoid the occurrence of hypovitaminosis-D-related neurological disorders.

\section{Non-Senile Hypovitaminosis D and}

Neuropsychopathological Disorders

While vitamin $\mathrm{D}$ is essential to the physiological functioning of the nervous system, vitamin D deficiency is associated with severe neurological disorders of various clinical manifestations depending on the nature of the dysfunction induced.

In rodents, the adult VDR-KO mouse model (i.e. deprived of functional VDR) presented with neuromuscular disorders, hypoacousia, and phosphocalcic homeosta- sis dysregulation associated with thalamic calcifications $[21,24]$. Moreover, the absence of VDR in the brain is responsible for behavioral disorders related to anxiety and motor disorders [25-31] (table 1). As an example, grooming did not follow the usual cephalocaudal progression of the wild phenotype; rather, it was anarchically performed by VDR-KO mice, with frequent interruptions and an atypical distribution with more paw grooming [25]. A modification of social behaviors, illustrated by aggression and aberrant maternal behaviors (such as negligence and cannibalism), was also observed [26]. Severe motor disorders, such as a limited ability to swim and reduced movements while swimming, have also been reported [27]; thus, suggesting the essential role of vitamin D in motor control.

In humans, VDR have been described in the cortex, cerebellum, and limbic system, which are key zones for the behavior. The genetic polymorphism of VDR could be responsible for severe psychiatric, neurologic, or neuropsychiatric phenotypes. As such, vitamin D deficiency has long been known to be accompanied by irritability, anxiety, depression, and psychosis [32, 33] (table 1).

\section{Schizophrenia}

According to the neurodevelopmental hypothesis of schizophrenia, prenatal vitamin D deficiency could be a risk factor for schizophrenia $[6,12,33,34]$ (table 1). An epidemiological link has been observed between the season of birth, latitude, and the occurrence of schizophrenia [6], with subjects who eventually develop a schizophrenic disorder being born significantly more frequently during winter time, in the higher latitudes of the globe, and in urban zones, i.e. where the maternal serum $25-\mathrm{OHD}_{2}$ concentrations (depending on the cutaneous action of solar UVB rays) are lower. Mackay-Sim et al. [35] suggested that low $25-\mathrm{OHD}_{2}$ levels during neuroformation could interact with susceptibility genes; thus, modifying the development of the brain through epigenetic regulation and favoring the occurrence of psychosis.

Animal experimentation supports this hypothesis: in schizophrenic rat models as well as in Developmental Vitamin $\mathrm{D}$ rat models, reduced frontal and left temporal production of ATP, mitochondrial density, and numbers of coding transcripts for pre-synaptic proteins (such as synapsin-2) were observed [9]. Furthermore, ApoE, which was identified in these Developmental Vitamin D model rats, is now considered a risk factor for schizophrenia. Similarly, Burne et al. [36] demonstrated that chronic pre- and postnatal vitamin $\mathrm{D}$ deficiencies in animals, 
unlike the deficiency observed in the early days of life, were risk factors for developing schizophrenia.

In humans, low serum $25-\mathrm{OHD}_{2}$ concentrations have been reported in patients with schizophrenia $[37,38]$. Such observations are consistent with the findings of the prospective study of McGrath et al. [39] who described a decreased incident risk of long-term schizophrenic psychosis in 9,114 subjects supplemented with vitamin D over the first year of life.

\section{Depression and Anxiety}

An association between vitamin D deficiency and anxio-depressive disorders is likely (table 1). Burne et al. [27] demonstrated a parallel between the behavioral and motor disorders observed in VDR-KO mice and animal models of depression. In humans, various theories have been suggested in order to explain seasonal mood swings. It has recently been suggested that vitamin $\mathrm{D}$, acting on the hypothalamic core (which plays a role in mood regulation $[4,40])$, could be the missing link between seasonal changes in photoperiod and seasonal mood swings [41, 42]. Data from epidemiological studies are coherent with such a hypothesis. As an example, Wilkins et al. [43] established that low serum $25-\mathrm{OHD}_{2}$ concentrations were closely related to active mood disorders in 80 subjects aged 65 years and older living at home. Other authors have also demonstrated that lower serum $25-\mathrm{OHD}_{2}$ and $1,25-(\mathrm{OH})_{2} \mathrm{D}_{3}$ concentrations are observed in depressive subjects compared to healthy subjects $[33,44,45]$. This data was indirectly confirmed in around 4,000 women aged 67 years on average by Silverman et al. [46] who established a link between depression and osteoporosis, with a higher risk of developing depression in women with a history of compressed vertebrae compared to women without such history. Nevertheless, this result has to be mitigated and potentially related to physical inactivity and functional impairment, both of which may increase with osteoporosis and have been independently associated with depression. Also, Oren et al. [47] found no significant differences between serum vitamin $\mathrm{D}$ concentrations in 15 depressed subjects compared to 15 healthy controls.

Clinical trials support the hypothesis of the efficacy of vitamin D supplementation on mood disorders. As an example, Gloth et al. [48], in a pilot study, administered 100,000 IU of vitamin D to 8 subjects with seasonal depression, while 7 other subjects were treated with phototherapy. Vitamin D was associated with improved depression scale results, while phototherapy was not. However, Dumville et al. [49] did not observe any im- provement in SF12 scale scores following 6 months'vitamin D supplementation (800 IU/day) in 1,621 women aged 70 years and older. It should be noted that the authors did not take into account the initial vitamin D status, which plays a major role in the efficiency of nonbone vitamin D effects, a deficiency being associated with a greater efficacy of supplementation. Furthermore, the daily prescribed vitamin $\mathrm{D}$ dose also seems to play a decisive role and should be at least 800 UI. In a prospective trial, Harris and Dawson-Hughes [50] also observed seasonal mood swings in 250 menopausal women, in spite of daily vitamin D supplementation at 400 IU.

\section{Epilepsy}

An association between vitamin D deficiency and epilepsy has been postulated (table 1). On the one hand, vitamin $\mathrm{D}$ deficiency could be explained by epilepsy treatment as valproate is a cytochrome $\mathrm{P} 450$ enzyme inhibitor that could potentially increase the catabolism of $25-\mathrm{OHD}_{2}$ to inactive metabolites 24,25 -dihydroxyvitamin [51]. However, based on the vitamin D neurosteroid regulation role, a scenario of reverse causation is also plausible and should be considered. Thus, in rachitic children, seizures accompanied by low calcium and 25$\mathrm{OHD}_{2}$ concentrations have been observed [52, 53], whereas long-term vitamin $\mathrm{D}$ supplementation led to a reduced incidence of these symptoms [54]. Furthermore, a direct antiepileptic effect of $1,25-(\mathrm{OH})_{2} \mathrm{D}_{3}$ was reported in mice $[23,55,56]$, suggesting a possible control of the regulation of epileptogenic focuses. Moreover, according to Kalueff and Tuohimaa [1], the vitamin-D-supplementation-related increased calcium concentration could lead to a reduced incidence of seizures in epileptic patients.

\section{Multiple Sclerosis}

Multiple sclerosis (MS) is an inflammatory demyelinating disorder of the CNS, the etiology of which could be related to environmental risk factors. Vitamin D deficiency - regulating cell proliferation and differentiation, as well as immunomodulation in the CNS [11-22] - could consequently be considered as a potential risk factor for MS (table 1).

Studying EAE - the animal model of human MS - has provided experimental support for such a hypothesis. Indeed, vitamin D deficiency was responsible for a worsening of symptoms [57], while supplementation could prevent $\mathrm{EAE}$ in mice or block its progression with a dosedependent effect $[57,58]$. This effect disappeared in 
VDR-KO EAE mice; thus highlighting the role of the VDR in the mediation of such action [22].

In humans, there are mainly epidemiological data, as low serum $25-\mathrm{OHD}_{2}$ concentrations have been associated with a high incidence of MS [59]. A mean $25-\mathrm{OHD}_{2}$ concentration below $20 \mathrm{ng} / \mathrm{ml}$ was described in $48-71 \%$ of MS subjects [60]. Furthermore, a $41 \%$ increase in the incidence of MS for a $20-\mathrm{ng} / \mathrm{ml} 25-\mathrm{OHD}_{2}$ drop was calculated in teenagers in the USA [61]. Moreover, the incidence of MS increases with latitude and decreased sunlight and cutaneous synthesis of vitamin D [62]. The symptomatology of MS is also improved during pregnancy [62], during which $1,25-(\mathrm{OH})_{2} \mathrm{D}_{3}$ levels are physiologically increased. Also, relapse rates are inversely associated with ambient UVB radiation and serum vitamin $D$ concentrations [63].

In addition, the association of VDR genotypes with MS has been explored in humans [64-66]. While Bsm1 and Apal polymorphisms assessed from $77 \mathrm{MS}$ cases and 95 healthy controls showed that the AA genotype and the A allele were significantly more prevalent in cases than in healthy controls, suggesting a risk factor for MS [64], no significant association between the polymorphisms rs11574010 (Cdx-2 A>G), rs10735810 (Fok1 T>C), or rs731236 (Taq1 C>T) and MS risk was observed in 136 MS cases and 235 controls [65]. Furthermore, a study on 212 MS cases and 289 controls showed no association of the Fok1 VDR gene polymorphism with MS [66].

Finally, it has to be noted that no correlation has been found between serum $25-\mathrm{OHD}_{2}$ and $\mathrm{T}_{1}$ gadolinium-enhancing or $\mathrm{T}_{2}$-weighted MRI lesions [67].

Despite these last negative data, Kampman et al. [68] recently reported a protective effect of the regular consumption of fish or cod liver oil (both high in vitamin D) on MS outcomes. Such results confirm the cohort data gathered from the Nurses' Health Study I and II, which demonstrated that daily dietary vitamin $\mathrm{D}$ intake was responsible for a $40 \%$ reduction in the prospective risk of developing MS in almost 200,000 initially healthy women [69].

\section{Cerebral Tumor}

Hypovitaminosis D is considered by some authors as a risk factor for tumor (table 1), while its experimental differentiation and antiproliferation properties could actually make vitamin $\mathrm{D}$ an antitumor agent $[1,11]$. As such, $1,25-(\mathrm{OH})_{2} \mathrm{D}_{3}$ induced the cellular death of rat glioma cell lines [70-72], and its in vitro efficacy was recently extended to human malignant cell lines [73-76].
Peripheral Neuropathy

Vitamin D status also seems to be associated with the peripheral nervous system as reduced nervous conduction speeds have been reported in women with a vitamin D deficiency [77], whereas the opposite effect was demonstrated after vitamin D and calcium supplementation of a 40-year-old man with idiopathic hypoparathyroidism [78]. Additionally, an improvement in symptomatic peripheral neuropathy was observed with QR-333, a local topical compound containing vitamin $\mathrm{D}$, in 34 subjects with diabetes in a controlled double-blind randomized multicentre trial [79].

Vitamin D therapy might also be useful as a neuroprotective strategy. As the protecting role of vitamin D increases with age [1], supplementation seems particularly useful in deficient elderly, especially as part of management strategies for gait disorders and neuropsychological decline.

\section{Senile Hypovitaminosis D and Neurological}

Senescence

From an epidemiological viewpoint, vitamin D deficiency is very frequent in older subjects, affecting more than $50 \%$ of subjects aged 65 years and older [80]. It has also been proven that vitamin $\mathrm{D}$ deficiency is associated with an increased risk of developing age-related diseases $[2,9,81]$. More specifically, a high prevalence of neurological disorders has been observed in these geriatric populations at risk of hypovitaminosis D: neuromuscular disorders and cognitive impairment affect respectively around 60 and $70 \%$ of subjects aged 75 years and older [82, 83]. Such observations support the hypothesis of a relationship between 'senile' hypovitaminosis D and neurological function impairment in older subjects.

\section{Neuromuscular Function and Gait}

Any motor behavior requires adequate motor coordination, and thus requires integrity of the muscular and neurological systems. At the muscular level, vitamin D regulates intramuscular and intramitochondrial calcium concentrations, facilitates excitation coupling, and consequently participates in the good functional equilibrium of type II muscle fibers [84]. Therefore, some authors have suggested that such vitamin-D-induced actions could influence the level of muscular strength in older adults [84, 85]. However, Annweiler et al. [85] recently highlighted the existence of contradictory elements concerning the association between vitamin $\mathrm{D}$ and muscular performance in older subjects, both in observational and interventional studies. Nevertheless, vitamin D supple- 
mentation seems to improve gait in the elderly and to prevent the occurrence of falls and their adverse consequences [84-89]: beyond a $26 \%$ reduction in the number of nonvertebral fractures [86], vitamin D supplementation at a daily dose of 800 IU in deficient subjects is responsible for a decreased number of falls in a given individual, but also for a reduced number of fallers, with a rate reduction reaching $22 \%[86,89]$. This data added to epidemiological studies showing that hypovitaminosis $\mathrm{D}$ was observed more frequently in older fallers compared to nonfallers [87]. Finally, hypovitaminosis-D-related motor performance impairment in older subjects has been shown to result in functional impairment and deteriorated gait speed, which became abnormally slow $[88,90$ 92]. Conversely, Verhaar et al. [93] and Bunout et al. [94] showed a significant improvement in gait speed after 6-9 months of vitamin D supplementation in deprived women aged 70 years and older, irrespective of their physical condition. Consequently, vitamin D supplementation of deficient older subjects seems to be a simple, easily accessible, and inexpensive prevention strategy to help combat the demographic and public health challenge of gait disorders.

\section{Cognitive Function: Alzheimer's Disease}

More than $10 \%$ of people over 65 years and $50 \%$ of people over 85 years develop dementia [82]. Alzheimer's disease (AD) represents $60-70 \%$ of these cases [95], and is a chronic neurodegenerative disease with insidious evolution caused by the complex interaction of genetic and environmental factors [95], potentially including hypovitaminosis D (table 1). Epidemiological studies revealed low serum $25-\mathrm{OHD}_{2}$ concentrations in subjects with AD [43, 96-98]. Wilkins et al. [43] found a significant positive association between serum $25-\mathrm{OHD}_{2} \mathrm{lev}-$ els and Clinical Dementia Rating/Short Blessed Test scores in 80 older subjects aged 65 years and over, living at home (40 subjects with $\mathrm{AD}$ and 40 non-demented subjects). Additionally, Przybelski et al. [99] and Oudshorn et al. [100] highlighted an association with the score obtained on the Mini Mental Status Examination. Similarly, Llewellyn et al. [101] demonstrated in 1,766 non-demented subjects or with mild cognitive impairment (mean age 78 years, $60 \%$ women) that the lowest serum vitamin $\mathrm{D}$ concentrations matched the highest risk of pathological Abbreviated Mental Test score. Wilkins et al. [102] also found a significant linear association between serum vitamin $\mathrm{D}$ concentration and the Short Blessed Test score among 60 elderly non-demented or mild cognitive impairment patients (mean age 75 years). Finally, Annweiler et al. [103] showed a significant positive association $(\mathrm{OR}=2.03, \mathrm{p}=0.012)$ between vitamin $\mathrm{D}$ deficiency $\left(25-\mathrm{OHD}_{2}<10 \mathrm{ng} / \mathrm{ml}\right)$ and a pathological score for Pfeiffer's Short Portable Mental State Questionnaire among 752 women (mean age 82 years). In contrast, 2 studies found no significant association $[32,104]$. First, Jorde et al. [32] unsuccessfully explored the linear association of serum vitamin D with 6 specific cognitive functions (working memory, episodic memory, speed of information processing, language, executive functions, and intelligence) in 148 older subjects with hyperparathyroidism (mean age 62 years, 46\% women). Second, McGrath et al. [104] found no significant positive logistic association between the quintiles of serum vitamin D concentrations and several specific cognitive tasks among 4,747 adults aged between 20 and 59 years (symbol-digit substitution coding speed: attention and episodic memory; serial digit learning trials to criterion: working memory). The choice of cognitive outcome appears to be critical, and explains the divergent results. It remains unclear which specific cognitive functions are affected in vitamin D deficiency and explain the link with impaired global composite cognitive scores. We suggest a close association of 'senile' hypovitaminosis D with impaired executive functions. Indeed, amongst 1,080 subjects (mean age 75 years, $76 \%$ women) free of neuropsychiatric disorders (epilepsy, schizophrenia, bipolar disorder, mental retardation, brain tumors, human immunodeficiency virus), Buell et al. [105] found a significant positive linear association between serum $25-\mathrm{OHD}_{2}$ concentrations and scores in tests exploring executive functions (trail making test: flexibility) and speed of information processing (digit symbol coding). Finally, an indirect relationship between a low bone mineral density (BMD) in senile osteoporosis - primarily related to vitamin D deficiency - and cognitive decline has been reported $[106,107]$. The authors did not specify whether low BMD was related to a recent loss of bone mass, to an early menopause, or to a low bone mass peak. However, Lui et al. [107] demonstrated that older women with rapid bone loss were at a higher risk of cognitive decline than those with a slower bone loss or a growing bone mass, independent of baseline BMD and without these differences being explained by functional status, the use of estrogens, or by ApoE.

From a molecular point of view, 2 proteins connected to the vitamin $\mathrm{D}$ system, the calbindin protein and the Klotho protein, have been associated to a reduced number of synapses in the hippocampus and to marked cognitive impairment $[106,108]$. Similarly, a significant re- 
duction in the number of VDR has been reported in $\mathrm{AD}$ [109], and their polymorphism was suggested to be involved in neuronal ageing and neurodegenerative diseases by impairing the neuroprotection and neuroregulation mechanisms of neurotrophic factors and calcium homeostasis [110]. Poduslo and Yin [111] thus demonstrated that 3 markers located near the VDR gene on chromosome 12 were associated with the development of AD. Additionally, Gezen-Ak et al. [110] demonstrated a significant association between VDR gene APA1 polymorphism and the occurrence of $\mathrm{AD}$, with the Aa genotype multiplying the risk of developing AD 2.3-fold compared to the AA genotype. Also in this study, the AATT combined genotype was more often present in healthy controls than in patients with $\mathrm{AD}$, suggesting a protective effect on AD [110]. However, no relationship with FOQ1 or TAQ1 polymorphisms has been observed [110, $112]$.

Current curative therapeutical strategies for $\mathrm{AD}$ primarily aim at fighting neuronal damage, making vitamin $\mathrm{D}$ the ideal candidate, with its neurotrophic, neuroprotective, and neurotransmission qualities. Among others, vitamin $\mathrm{D}$ is responsible for increased acetylcholine concentrations in rat brain [11], and for reducing in vitro glutamate neurotoxicity and dopaminergic toxins [20]. These detoxification properties seem to be of particular importance, some authors having suggested the central role of oxidative stress in the pathophysiology of neurodegenerative disorders [113]. As an example, there is a probability that detoxification processes are locally altered within hippocampal CA1 and CA2 regions, which play a major part in cognitive processes and are more vulnerable during $\mathrm{AD}[4,109,114]$. It has been demonstrated that vitamin D reduces inflammatory disorders and hippocampal degenerative processes in elderly rats, and is also responsible for decreased levels of the biological markers of ageing [10, 114, 115]. In humans, Rondanelli et al. [116] showed a significant reverse correlation between dietary vitamin $\mathrm{D}$ intakes and cognitive test performance $(\mathrm{r}=0.24, \mathrm{p}<0.05)$ in 69 community-dwelling healthy older subjects (mean age 84 years). To the best of our knowledge, no prospective clinical trial has been able to demonstrate the efficacy of vitamin D intake on cognition in humans. Only 1 prospective study showed that ergocalciferol (50,000 IU, 3 times weekly) - although safely normalizing serum $25-\mathrm{OHD}_{2}$ in 25 nursing home residents with low $25-\mathrm{OHD}_{2}$ status at baseline - did not improve clock-drawing test performance, verbal fluency, and neuropsychiatric inventory scores after 4 weeks of treatment [117].
Parkinson's Disease

Parkinson's disease (PD) is a neurodegenerative disease affecting the central dopaminergic pathways by damaging neuroprotective processes [118], which hypovitaminosis D in elderly subjects could be responsible for [119-125] (table 1). Vitamin D deficiency was indeed observed in Parkinson's patients, irrespective of their functional state [119-121]. VDR gene Bsm1 polymorphism was recently associated with PD: the allele b and BB homozygosity having been more frequently observed in subjects with Parkinson's disease, compared to healthy controls [122].

These observations were confirmed by animal models. The dopaminergic cell degeneration induced by the intraventricular administration of 6-hydroxydopamine in rats made an animal model similar to PD in humans. It was demonstrated that long-term vitamin $\mathrm{D}$ supplementation $[123,124]$ could reduce 6-hydroxydopamine neurotoxicity by increasing the quantity of GDNF in the substantia nigra, but not in the striatum, and by improving hypokinesia and neuronal toxicity.

To the best of our knowledge, in humans, only 1 case report presented an improvement in PD symptoms in a 47-year-old male patient supplemented with calcium and vitamin $\mathrm{D}$ at a dose of 4,000 IU daily, following resistance to the usual antiparkinsonian treatment, with persistent improvement at 1 year [125]. Using vitamin D in human PD therefore seems promising, although larger investigations such as an interventional prospective study are required.

\section{Conclusion}

An increasing number of elements are in favor of a positive association between vitamin $\mathrm{D}$ and neurological status, vitamin D deficiency being associated with neurological disorders. The lack of negative published data can probably be explained by publication bias [126], but also highlight the reliability of the association. Whether in humans or in animals, vitamin $\mathrm{D}$, a neurosteroid hormone, seems to occupy a central place in the regulation of neurotransmission, neuroprotection, neuroimmunomodulation, and cerebral networks and processes throughout life. Motor, psychological, and social behaviors that are adapted to individuals and to the surrounding environment are thereby induced. However, the high prevalence of hypovitaminosis $\mathrm{D}$ in the populations of developed countries, and particularly in older adults, seems to play a part in cerebral and neuromus- 
cular ageing, along with an alteration of neuronal processes and a deterioration of the functions these processes fulfill. It is now agreed that inadequate vitamin D intake in elderly subjects cannot be effectively handled with dietary measures or food supplementation alone [127]. Such observations might reinforce the pharmacological potential of vitamin $\mathrm{D}$ in neuroimmunological and neurodegenerative disease management strategies.

\section{References}

$\checkmark 1$ Kalueff AV, Tuohimaa P: Neurosteroid hormone vitamin $\mathrm{D}$ and its utility in clinical nutrition. Curr Opin Clin Nutr Metab Care 2007;10:12-19.

-2 Zittermann A: Vitamin D in preventive medicine: are we ignoring the evidence? $\mathrm{Br}$ Nutr 2003;89:552-572.

- 3 Prufer K, Veenstra TD, Jirikowski GF, Kumar R: Distribution of 1,25-dihydroxyvita$\min \mathrm{D}_{3}$ receptor immunoreactivity in the rat brain and spinal cord. J Chem Neuroanat 1999;16:135-145.

4 Eyles DW, Smith S, Kinobe R, Hewison M, McGrath JJ: Distribution of the vitamin D receptor and 1 alpha-hydroxylase in human brain. J Chem Neuroanat 2005;29:21-30.

5 Veenstra TD, Prufer K, Koenigsberger C, Brimijoin SW, Grande JP, Kumar R: 1,25-Dihydroxyvitamin $\mathrm{D}_{3}$ receptors in the central nervous system of the rat embryo. Brain Res 1998;804:193-205.

6 McGrath J: Hypothesis: Is low prenatal vitamin $\mathrm{D}$ a risk-modifying factor for schizophrenia? Schizophr Res 1999;40:173-177.

7 Eyles D, Brown J, Mackay-Sim A, McGrath J, Feron F: Vitamin D-3 and brain development. Neurosci 2003;118:641-653.

$\checkmark 8$ Eyles D, Almeras L, Benech P, Patatian A, Mackay-Sim A, McGrath J, Féron F: Developmental vitamin $\mathrm{D}$ deficiency alters the expression of genes encoding mitochondrial, cytoskeletal and synaptic proteins in the adult rat brain. J Steroid Biochem Mol Biol 2007;103:538-545.

-9 Almeras L, Eyles D, Benech P, Laffite D, Villard C, Patatian A, Boucraut J, Mackay-Sim A, McGrath J, Féron F: Developmental vitamin $\mathrm{D}$ deficiency alters brain protein expression in the adult rat: implications for neuropsychiatric disorders. Proteomics 2007; 7: 769-780.

10 Langub MC, Herman JP, Malluche HH, Koszewski NJ: Evidence of functional vitamin $\mathrm{D}$ receptors in rat hippocampus. Neuroscience 2001;104:49-56.

11 Garcion E, Wion-Barbot N, Montero-Menei CN, Berger F, Wion D: New clues about vitamin $\mathrm{D}$ functions in the nervous system. Trends Endocrinol Metab 2002;13:100-105.

12 McGrath J, Féron F, Eyles D, Mackay-Sim A: Vitamin D: the neglected neurosteroid? Trends Neurosci 2001;24:570-572.
13 Zehnder D, Bland R, Williams MC, McNinch RW, Howie AJ, Steward PM, Hewison M: Extrarenal expression of 25-hydroxyvitamin d(3)-1 alpha-hydroxylase. J Clin Endocrinol Metab 2001;86:888-894.

14 Brown J, Bianco JI, McGrath JJ, Eyles DW: 1,25-Dihydroxyvitamin D-3 induces nerve growth factor, promotes neurite outgrowth and inhibits mitosis in embryonic rat hippocampal neurons. Neurosci Lett 2003;343: 139-143.

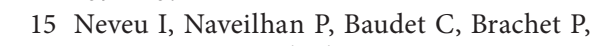
Metsis M: 1,25-Dihydroxyvitamin $\mathrm{D}_{3}$ regulates NT-3, NT-4 but not BDNF mRNA in astrocytes. Neuroreport 1994;6:124-126.

16 Wang Y, Chiang YH, Su TP, Hayashi T, Morales $\mathrm{M}$, Hoffer BJ, Lin SZ: Vitamin $\mathrm{D}_{3}$ attenuates cortical infarction induced by middle cerebral arterial ligation in rats. Neuropharmacology 2000;39:873-880.

17 Riaz S, Malcangio M, Miller M, Tomlinson DR: A vitamin $\mathrm{D}_{3}$ derivative (CB1093) induces nerve growth factor and prevents neurotrophic deficits in streptozotocindiabetic rats. Diabetologia 1999;42:1308-1313.

18 De Viragh PA, Haglid KG, Celio MR: Parvalbumin increases in the caudate putamen of rats with vitamin D hypervitaminosis. Proc Natl Acad Sci USA 1989;86:3887-3890.

19 Garcion E, Sindji L, Nataf S, Brachet P, Darcy F, Montero-Menei CN: Treatment of experimental autoimmune encephalomyelitis in rat by 1,25-dihydroxyvitamin $\mathrm{D}_{3}$ leads to early effects within the central nervous system. Acta Neuropathol 2003;105:438-448.

20 Ibi M, Sawada H, Nakanishi M, Kume T, Katsuki H, Kaneko S, Shimohama S, Akaike A: Protective effects of 1 alpha,25-(OH)(2)D(3) against the neurotoxicity of glutamate and reactive oxygen species in mesencephalic culture. Neuropharmacology 2001;40:761771.

21 Kalueff A, Loseva E, Haapasalo H, Rantala I, Keranen J, Lou YR, Minasyan A, Keisala T, Miettinen S, Kuuslahti M, Tuchimaa P: Thalamic calcification in vitamin $\mathrm{D}$ receptor knockout mice. Neuroreport 2006;17:717721.

22 Meehan TF, DeLuca HF: The vitamin D receptor is necessary for 1alpha,25-dihydroxyvitamin $\mathrm{D}_{3}$ to suppress experimental autoimmune encephalomyelitis in mice. Arch Biochem Biophys 2002;408:200-204.
23 Kalueff AV, Minasyan A, Tuohimaa P: Anticonvulsant effects of 1,25-dihydroxyvitamin $D$ in chemically induced seizures in mice. Brain Res Bull 2005;67:156-160.

24 Burne TH, McGrath JJ, Eyles DW, MackaySim A: Behavioral characterization of vitamin D receptor knockout mice. Behav Brain Res 2005;157:299-308.

25 Kalueff AV, Lou YR, Laaksi I, Tuohimaa P: Abnormal behavioral organization of grooming in mice lacking the vitamin D receptor gene. J Neurogenet 2005;19:1-24.

26 Kalueff AV, Keisala T, Minasyan A, Kuuslahti M, Miettinen S, Tuohimaa P: Behavioural anomalies in mice evoked by 'Tokyo' disruption of the vitamin $\mathrm{D}$ receptor gene. Neurosci Res 2006;54:254-260.

27 Burne TH, Johnston AN, McGrath J, Mackay-Sim A: Swimming behaviour and postswimming activity in vitamin $\mathrm{D}$ receptor knockout mice. Brain Res Bull 2006;69:7478.

28 Burne TH, Becker A, Brown J, Eyles DW, Mackay-Sim A, McGrath JJ: Transient prenatal vitamin $D$ deficiency is associated with hyperlocomotion in adult rats. Behav Brain Res 2004;154:549-555.

29 Becker A, Eyles DW, McGrath JJ, Grecksch G: Transient prenatal vitamin D deficiency is associated with subtle alterations in learning and memory functions in adult rats. Behav Brain Res 2005;161:306-312.

- 30 O’Loan J, Eyles DW, Kesby J, Ko P, McGrath JJ, Burne TH: Vitamin D deficiency during various stages of pregnancy in the rat; its impact on development and behaviour in adult offspring. Psychoneuroendocrinology 2007; 32:227-234

- 31 Kalueff AV, Lou YR, Laaksi I, Tuohimaa P: Increased anxiety in mice lacking vitamin $\mathrm{D}$ receptor gene. Neuroreport 2004;15:12711274.

32 Jorde R, Waterloo K, Saleh F, Haug E, Svartberg J: Neuropsychological function in relation to serum parathyroid hormone and serum 25-hydroxyvitamin $\mathrm{D}$ levels: the Tromso study. J Neurol 2006;253:464-470.

- 33 Ozer S, Ulusahin A, Ulusoy S, Okur H, Coskun T, Tuncali T, Gogus A, Akarsu AN: Is vitamin $\mathrm{D}$ hypothesis for schizophrenia valid? Independent segregation of psychosis in a family with vitamin dependent rickets type IIA. Prog Neuropsychopharmacol Biol Psychiatry 2004;28:255-266. 
-34 Yan J, Feng J, Craddock N, Jones IR, Cook EH Jr, Goldman D, Heston LL, Chen J, Burkhart P, Li W, Shibayama A, Sommer SS: Vitamin D receptor variants in 192 patients with schizophrenia and other psychiatric diseases. Neurosci Lett 2005;380:37-41.

-35 Mackay-Sim A, Féron F, Eyles D, Burne T, McGrath J: Schizophrenia, vitamin D, and brain development. Int Rev Neurobiol 2004; 59:351-380.

-36 Burne TH, Féron F, Brown J, Eyles DW, McGrath JJ, Mackay-Sim A: Combined prenatal and chronic postnatal vitamin D deficiency in rats impairs prepulse inhibition of acoustic startle. Physiol Behav 2004;81:651-655.

-37 Schneider B, Weber B, Frensch A, Stein J, Fritz J: Vitamin D in schizophrenia, major depression and alcoholism. J Neural Trans 2000;107:839-842.

>38 Bergemann N, Parzer P, Mundt C, Auler B: High bone turnover but normal bone mineral density in women suffering from schizophrenia. Psychol Med 2008;38:1195-1201.

-39 McGrath J, Saari K, Hakko H, Jokelainen J, Jones P, Jarvelin MR, Chant D, Isohanni M: Vitamin D supplementation during the first year of life and risk of schizophrenia: a Finnish birth cohort study. Schizophr Res 2004; 67:237-245

40 Lam RW, Levitan RD: Pathophysiology of seasonal affective disorder: a review. J Psychiatry Neurosci 2000;25:469-480.

41 Berk M, Sanders KM, Pasco JA, Jacka FN, Williams LJ, Hayles AL, Dodd S: Vitamin D deficiency may play a role in depression. Med Hypotheses 2007;69:1316-1319.

42 Stumpf WE, Privette TH: The steroid hormone of sunlight soltriol (vitamin D) as a seasonal regulator of biological activities and photoperiodic rhythms. J Steroid Biochem Mol Biol 1991;39:283-289.

$\checkmark 43$ Wilkins CH, Sheline YI, Roe CM, Birge SJ, Morris JC: Vitamin D deficiency is associated with low mood and worse cognitive performance in older adults. Am J Geriatr Psychiatry 2006; 14:1032-1040.

-44 Armstrong DJ, Meenagh GK, Bickle I, Lee AS, Curran ES, Finch MB: Vitamin D deficiency is associated with anxiety and depression in fibromyalgia. Clin Rheumatol 2007; 26:551-554

-45 Hoogendijk WJ, Lips P, Dik MG, Deeg DJ, Beekman AT, Penninx BW: Depression is associated with decreased 25-hydroxyvitamin $\mathrm{D}$ and increased parathyroid hormone levels in older adults. Arch Gen Psychiatry 2008; 65:508-512.

-46 Silverman SL, Shen W, Minshall ME, Xie S, Moses KH: Prevalence of depressive symptoms in postmenopausal women with low bone mineral density and/or prevalent vertebral fracture: results from the Multiple Outcomes of Raloxifene Evaluation (MORE) study. J Rheumatol 2007;34:140-144.
47 Oren DA, Schulkin J, Rosenthal NE: 1,25 $(\mathrm{OH}) 2$ vitamin $\mathrm{D}_{3}$ levels in seasonal affective disorder: effects of light. Psychopharmacology (Berl) 1994;116:515-516.

48 Gloth FM 3rd, Alam W, Hollis B: Vitamin D versus broad spectrum phototherapy in the treatment of seasonal affective disorder. Nutr Health Aging 1999;3:5-7.

49 Dumville JC, Miles JN, Porthouse J, Cockayne S, Saxon L, King C: Can vitamin D supplementation prevent winter-time blues? A randomised trial among older women. J Nutr Health Aging 2006;10:151-153.

50 Harris S, Dawson-Hughes B: Seasonal mood changes in 250 normal women. Psychiatry Res 1993;49:77-87.

51 Pack A: Bone health in people with epilepsy: is it impaired and what are the risk factors? Seizure 2008;17:181-186.

52 Rodd C, Mushcab SA: Hypocalcemic seizures secondary to nutritional vitamin $\mathrm{D}$ deficiency in 3 infants fed soy formula. Clin Pediatr (Phila) 2005;44:455-457.

53 Ali FE, Al-Bustan MA, Al-Busairi WA, AlMulla F: Loss of seizure control due to anticonvulsant-induced hypocalcemia. Ann Pharmacother 2004;38:1002-1005.

54 Christiansen C, Rodbro P, Sjo O: 'Anticonvulsant action' of vitamin $\mathrm{D}$ in epileptic patients? A controlled pilot study. Br Med J 1974;2:258-259.

55 Siegel A, Malkowitz L, Moskovits MJ, Christakos S: Administration of 1,25-dihydroxyvitamin $\mathrm{D}_{3}$ results in the elevation of hippocampal seizure threshold levels in rats. Brain Res 1984;298:125-129.

56 Borowicz KK, Morawska M, Furmanek-Karwowska K, Luszczki JJ, Czuczwar SJ: Cholecalciferol enhances the anticonvulsant effect of conventional antiepileptic drugs in the mouse model of maximal electroshock. Eur J Pharmacol 2007;573:111-115.

57 Cantorna MT, Hayes CE, DeLuca HF: 1,25Dihydroxyvitamin $\mathrm{D}_{3}$ reversibly blocks the progression of relapsing encephalomyelitis, a model of multiple sclerosis. Proc Natl Acad Sci USA 1996;93:7861-7864.

58 Spach KM, Hayes CE: Vitamin $\mathrm{D}_{3}$ confers protection from autoimmune encephalomyelitis only in female mice. J Immunol 2005; 175:4119-4126.

59 Torkildsen $\varnothing$, Knappskog PM, Nyland HI Myhr KM: Vitamin D-dependent rickets as a possible risk factor for multiple sclerosis. Arch Neurol 2008;65:809-811.

60 Smolders J, Damoiseaux J, Menheere P, Hupperts R: Vitamin D as an immune modulator in multiple sclerosis, a review. J Neuroimmunol 2008;194:7-17.

61 Munger KL, Levin LI, Hollis BW, Howard NS, Ascherio A: Serum 25-hydroxyvitamin D levels and risk of multiple sclerosis. JAMA 2006;296:2832-2838.

-62 Niino M, Fukazawa T, Kikuchi S, Sasaki H: Therapeutic potential of vitamin D for multiple sclerosis. Curr Med Chem 2008;15:499_ 505.
63 Tremlett H, van der Mei I, Pittas F, Blizzard L, Paley G, Mesaros D, Woodbaker R, Numez M, Dwyer T, Taylor BV, Ponsonby AL: Monthly ambient sunlight, infections and relapse rates in multiple sclerosis. Neuroepidemiology 2008;31:271-279.

64 Niino M, Fukazawa T, Yabe I, Kikuchi S, Sasaki $\mathrm{H}$, Tashiro K: Vitamin D receptor gene polymorphism in multiple sclerosis and the association with HLA class II alleles. J Neurol Sci 2000;177:65-71.

65 Dickinson J, Perera D, van der Mei A, Ponsonby AL, Polanowski A, Thomson R, Taylor B, McKay J, Stankovich J, Dwyer T: Past environmental sun exposure and risk of multiple sclerosis: a role for the Cdx-2 Vitamin D receptor variant in this interaction. Mult Scler 2009; 15:563-570.

66 Smolders J, Damoiseaux J, Menheere P, Tervaert JW, Hupperts R: Fok-I vitamin D receptor gene polymorphism (rs10735810) and vitamin $\mathrm{D}$ metabolism in multiple sclerosis. J Neuroimmunol 2009;207:117-121.

67 Soilu-Hänninen M, Laaksonen M, Laitinen I, Erälinna JP, Lilius EM, Mononen I: A longitudinal study of serum 25-hydroxyvitamin D and intact PTH levels indicate the importance of vitamin D and calcium homeostasis regulation in multiple sclerosis. J Neurol Neurosurg Psychiatry 2008;79:152157.

68 Kampman MT, Wilsgaard T, Mellgren SI: Outdoor activities and diet in childhood and adolescence relate to MS risk above the Arctic Circle. J Neurol 2007;254:471-477.

-69 Munger KL, Zhang SM, O’Reilly E, Hernan MA, Olek MJ, Willett WC, Ascherio A: Vitamin D intake and incidence of multiple sclerosis. Neurology 2004;62:60-65.

$>70$ Elias J, Marian B, Edling C, Lachmann B, Noe CR, Rolf SH, Schuster I: Induction of apoptosis by vitamin D metabolites and analogs in a glioma cell line. Recent Results Cancer Res 2003;164:319-321.

71 Naveilhan P, Berger F, Haddad K, Barbot N, Benabid AL, Brachet P, Wion D: Induction of glioma cell death by $1,25(\mathrm{OH}) 2$ vitamin $\mathrm{D}_{3}$ : towards an endocrine therapy of brain tumors? J Neurosci Res 1994;37:271-277.

72 Davoust N, Wion D, Chevalier G, Garabedian M, Brachet P, Couez D: Vitamin D receptor stable transfection restores the susceptibility to 1,25-dihydroxyvitamin $\mathrm{D}_{3}$ cytotoxicity in a rat glioma-resistant clone. J Neurosci Res 1998;52:210-219.

73 Trouillas P, Honnorat J, Bret P, Jouvet A, Gerard JP: Redifferentiation therapy in brain tumors: long-lasting complete regression of glioblastomas and an anaplastic astrocytoma under long term $1 \alpha$-hydroxycholecalciferol. J Neurooncol 2001;51:57-66. 
74 Diesel B, Radermacher J, Bureik M, Bernhardt R, Seifert M, Reichrath J, Fischer U, Meese E: Vitamin $\mathrm{D}_{3}$ metabolism in human glioblastoma multiforme: functionality of CYP27B1 splice variants, metabolism of calcidiol, and effects of calcitriol. Clin Cancer Res 2005;11:5370-5380.

75 Magrassi L, Butti G, Pezzotta S, Infuso L, Milanesi G: Effects of vitamin D and retinoic acid on human glioblastoma cell lines. Acta Neurochir (Wien) 1995;133:184-190.

76 Van Ginkel PR, Yang W, Marcet MM, Chow CC, Kulkarni AD, Darjatmoko S, Lindstrom MJ, Lokken J, Bhattacharya S, Albert DM: 1 alpha-Hydroxyvitamin $\mathrm{D}_{2}$ inhibits growth of human neuroblastoma. J Neurooncol 2007;85:255-262.

-77 Skaria J, Katiyar BC, Srivastava TP, Dube B: Myopathy and neuropathy associated with osteomalacia. Acta Neurol Scand 1975;51: 37-58.

78 Goswami R, Bhatia M, Goyal R, Kochupillai $\mathrm{N}$ : Reversible peripheral neuropathy in idiopathic hypoparathyroidism. Acta Neurol Scand 2002;105:128-131.

79 Valensi P, Le Devehat C, Richard JL, Farez C Khodabandehlou T, Rosenbloom RA, LeFante C: A multicenter, double-blind, safety study of QR-333 for the treatment of symptomatic diabetic peripheral neuropathy: a preliminary report. J Diabetes Complications 2005;19:247-253.

80 Gloth FM 3rd, Gundberg CM, Hollis BW, Haddad JG Jr, Tobin JD: Vitamin D deficiency in homebound elderly persons. JAMA 1995;274:1683-1686.

-81 Sutra del Galy A, Bertrand M, Bigot F, Abraham P, Thomlinson R, Paccalin M, Beauchet O, Annweiler C: Vitamin D deficiency and acute care in geriatrics inpatients. J Am Geriatr Soc 2009;57:1721-1723.

82 Camicioli RM, Kaye JA, Brummel-Smith K: Recognition of neurologic diseases in geriatric inpatients. Acta Neurol Scand 1998;97: 265-270.

83 Sudarsky L: Gait disorders: prevalence, morbidity, and etiology. Adv Neurol 2001;87: 111-117.

84 Annweiler C, Bridenbaugh S, Schott AM, Berrut G, Kressig RW, Beauchet O: Vitamin $\mathrm{D}$ and muscle function: new prospects? Biofactors 2009;35:3-4.

-85 Annweiler C, Schott AM, Berrut G, Fantino $\mathrm{B}$, Beauchet O: Vitamin D-related changes in physical performance: a systematic review. J Nutr Health Aging 2009;13:893-898.

86 Bischoff-Ferrari HA, Willett WC, Wong JB, Giovannucci E, Dietrich T, Dawson-Hughes $\mathrm{B}$ : Fracture prevention with vitamin $\mathrm{D}$ supplementation: a meta-analysis of randomized controlled trials. JAMA 2005;293:22572264.

87 Holick MF: Optimal vitamin D status for the prevention and treatment of osteoporosis. Drugs Aging 2007;24:1017-1029.
88 Bischoff-Ferrari HA, Dietrich T, Orav EJ, Hu FB, Zhang Y, Karlson EW, Dawson-Hughes B: Higher 25-hydroxyvitamin D concentrations are associated with better lower-extremity function in both active and inactive persons aged $>$ or $=60$ years. Am J Clin Nutr 2004;80:752-758

-89 Jackson C, Gaugris S, Sen SS, Hosking D The effect of cholecalciferol (vitamin $\mathrm{D}_{3}$ ) on the risk of fall and fracture: a meta-analysis. QJM 2007;100:185-192.

90 Annweiler C, Schott AM, Berrut G, Herrmann FR, Beauchet O: OC10 - preventing osteoporosis: cross-sectional relationship between serum 25-hydroxyvitamin D concentration and walking speed in the EPIDOS cohort. Abstr IOF World Congr Osteoporosis, Bangkok, December 3-7, 2008. Osteoporos Int 2008;19:S225-S512.

-91 Kwon J, Suzuki T, Yoshida H, Kim H, Yoshida Y, Iwasa $\mathrm{H}$ : Concomitant lower serum albumin and vitamin $\mathrm{D}$ levels are associated with decreased objective physical performance among Japanese community-dwelling elderly. Gerontology 2007;53:322-328.

92 Gerdhem P, Ringsberg KA, Obrant KJ, Akesson K: Association between 25-hydroxyvitamin D levels, physical activity, muscle strength and fractures in the prospective population-based OPRA Study of Elderly Women. Osteoporos Int 2005; 16:1425-1431.

$\$ 93$ Verhaar HJ, Samson MM, Jansen PA, de Vreede PL, Manten JW, Duursma SA: Muscle strength, functional mobility and vitamin D in older women. Aging (Milano) 2000;12:455-460

$\$ 94$ Bunout D, Barrera G, Leiva L, Gattas V, de la Maza MP, Avendaño M, Hirsch S: Effects of vitamin D supplementation and exercise training on physical performance in Chilean vitamin D deficient elderly subjects. Exp Gerontol 2006;41:746-452.

95 Rocca WA, Hofman A, Brayne C, Breteler MM, Clarke M, Copeland JR, Dartigues JF, Engedal K, Hagnell O, Heeren TJ: Frequency and distribution of Alzheimer's disease in Europe: a collaborative study of 1980-1990 prevalence findings. The EURODEM-Prevalence Research Group. Ann Neurol 1991;30 381-390.

96 Annweiler C, Allali G, Allain P, Bridenbaugh S, Kressig RW, Beauchet O: Vitamin D and cognitive performance: a systematic review. Eur J Neurol 2009;16:1083-1089.

-97 Miya K, Morimoto S, Fukuo K, Imanaka S, Shiraishi T, Yamamato H, Kitano S, Miyashita Y, Inoue T, Hirotani J: Cognitive function and calcium-related factors in elderly female subjects. Nippon Ronen Igakkai Zassh 1991;28:34-39.

98 Sato Y, Asoh T, Oizumi K: High prevalence of vitamin $\mathrm{D}$ deficiency and reduced bone mass in elderly women with Alzheimer's disease. Bone 1998;23:555-557.
-99 Przybelski RJ, Binkley NC: Is vitamin D important for preserving cognition? A positive correlation of serum 25-hydroxyvitamin D concentration with cognitive function. Arch Biochem Biophys 2007;460: 202-205.

100 Oudshorn C, Mattace-Raso FUS, Van der Velde N, Colin EM, Van der Cammen TJM: Higher Serum Vitamin $\mathrm{D}_{3}$ levels are associated with better cognitive test performance in patients with Alzheimer's disease. Dement Geriatr Cogn Disord 2008;25:539543.

101 Llewellyn DJ, Langa K, Lang I: Serum 25-hydroxyvitamin D concentration and cognitive impairment. J Geriatr Psychiatry Neurol 2009;22:188-195.

102 Wilkins CH, Birge SJ, Sheline YI, Morris JC: Vitamin D deficiency is associated with worse cognitive performance and lower bone density in older African Americans. J Natl Med Assoc 2009;101:349-354.

103 Annweiler C, Schott AM, Allali G, Bridenbaugh S, Kressig RW, Allain P, Herrmann FR, Beauchet O: Association of vitamin D deficiency with cognitive impairment in older women: cross-sectional study. Neurology 2010;74:27-32.

104 McGrath J, Scragg R, Chant D, Eyles D, Burne T, Obradovic D: No association between serum 25-hydroxyvitamin $\mathrm{D}_{3}$ level and performance on psychometric tests in NHANES III. Neuroepidemiology 2007;29: 49-54.

105 Buell JS, Scott TM, Dawson-Hughes B, Dallal GE, Rosenberg IH, Folstein MF, Tucker $\mathrm{KL}$ : Vitamin D is associated with cognitive function in elders receiving home health services. J Gerontol A Biol Sci Med Sci 2009; 64:888-895.

106 Nagai T, Yamada K, Kim HC, Kim YS, Noda Y, Imura A, Nabeshima Y, Nabeshima T: Cognition impairment in the genetic model of aging Klotho gene mutant mice: a role of oxidative stress. FASEB J 2003; 17: $50-52$.

107 Lui LY, Stone K, Cauley JA, Hillier T, Yaffe $\mathrm{K}$ : Bone loss predicts subsequent cognitive decline in older women: the study of osteoporotic fractures. J Am Geriatr Soc 2003;51: $38-43$.

108 Sonnenberg J, Luine VN, Krey LC, Christakos S: 1,25-Dihydroxyvitamin $\mathrm{D}_{3}$ treatment results in increased choline acetyltransferase activity in specific brain nuclei. Endocrinology 1986;118:1433-1439.

109 Sutherland MK, Somerville MJ, Yoong LK, Bergeron C, Haussler MR, McLachlan DR: Reduction of vitamin $\mathrm{D}$ hormone receptor mRNA levels in Alzheimer as compared to Huntington hippocampus: correlation with calbindin-28k mRNA levels. Brain Res Mol Brain Res 1992;13:239-250. 
110 Gezen-Ak D, Dursun E, Ertan T, Hanağasi H, Gürvit H, Emre M, Eker E, Oztürk M, Engin F, Yilmazer S: Association between vitamin $\mathrm{D}$ receptor gene polymorphism and Alzheimer's disease. Tohoku J Exp Med 2007;212:275-282.

$\checkmark 111$ Poduslo SE, Yin X: Chromosome 12 and late-onset Alzheimer's disease. Neurosci Lett 2001;310:188-190.

- 112 Luedecking-Zimmer E, DeKosky ST, Nebes R, Kamboh MI: Association of the 3' UTR transcription factor LBP-1c/CP2/LSF polymorphism with late-onset Alzheimer's disease. Am J Med Genet B Neuropsychiatr Genet 2003;117B:114-117.

-113 Dubinina EE, Kovrugina SV, Konovalov PV: The factors of oxidative stress in neurodegenerative diseases (vascular dementia, Alzheimer disease). Adv Gerontol 2007;20: 109-113.

-114 Brewer LD, Porter NM, Kerr DS, Landfield PW, Thibault O: Chronic 1alpha,25-(OH)2 vitamin $\mathrm{D}_{3}$ treatment reduces Ca2p-mediated hippocampal biomarkers of ageing. Cell Calcium 2006;40:277-286.

115 Moore ME, Piazza A, McCartney Y, Lynch MA: Evidence that vitamin $D_{3}$ reverses agerelated inflammatory changes in the rat hippocampus. Biochem Soc Trans 2005;33: 573-577.
116 Rondanelli M, Trotti R, Opizzi A, Solerte SB: Relationship among nutritional status, pro/antioxidant balance and cognitive performance in a group of free-living healthy elderly. Minerva Med 2007;98:639-645.

-117 Przybelski R, Agrawal S, Krueger D, Engelke JA, Walbrun F, Binkley N: Rapid correction of low vitamin $\mathrm{D}$ status in nursinghome residents. Osteoporos Int 2008;19: 1621-1628.

118 Riederer P, Sian J, Gerlach M: Is there neuroprotection in Parkinson syndrome? J Neurol 2000;247:8-11.

119 Sato Y, Kikuyama M, Oizumi K: High prevalence of vitamin D deficiency and reduced bone mass in Parkinson's disease. Neurology 1997;49:1273-1278.

120 Petroni ML, Albani G, Bicchiega V, Baudo S, Vinci C, Montesano A, Izzo G, Bertocco P, Mazzotta S, Zorzetto E, Balzola F, Mauro A: Body composition in advanced-stage Parkinson's disease. Acta Diabetol 2003;40: S187-S190.
121 Evatt ML, Delong MR, Khazai N, Rosen A, Triche S, Tangpricha V: Prevalence of vitamin D insufficiency in patients with Parkinson disease and Alzheimer disease. Arch Neurol 2008;65:1348-1352.

122 Kim JS, Kim YI, Song C, Yoon I, Park JW, Choi YB, Kim HT, Lee KS: Association of vitamin $\mathrm{D}$ receptor gene polymorphism and Parkinson's disease in Koreans. J Korean Med Sci 2005;20:495-498.

123 Wang JY, Wu JN, Cherng TL, Hoffer BJ, Chen $\mathrm{HH}$, Borlongan CV, Wang Y: Vitamin $\mathrm{D}(3)$ attenuates 6-hydroxydopamine-induced neurotoxicity in rats. Brain Res 2001; 904:67-75.

124 Smith MP, Fletcher-Turner A, Yurek DM, Cass WA: Calcitriol protection against dopamine loss induced by intracerebroventricular administration of 6-hydroxydopamine. Neurochem Res 2006;31:533-539.

125 Derex L, Trouillas P: Reversible parkinsonism, hypophosphoremia, and hypocalcemia under vitamin D therapy. Mov Disord 1997;12:612-613.

126 Sackett DL: Bias in analytic research. J Chronic Dis 1979;32:51-63.

127 Nowson C: Vitamin D status of Australians: Impact of Changes to Mandatory Fortification of Margarine with Vitamin D. i Canberra, Australia and New Zealand Food Authority, 2001. 